\title{
PENINGKATAN PROFESIONALITAS GURU DALAM PENYUSUNAN EVALUASI BERBASIS THINKING ANALYSIS BAGI GURU MATEMATIKA
}

\author{
Abdulloh Jaelani ${ }^{1)}$, Inna Kuswandari ${ }^{2)}$, Cicik Alfiniyah ${ }^{3)}$ \\ ${ }^{1,2,3}$ Fakultas Sains dan Teknologi, Universitas Airlangga \\ Email : ${ }^{1}$ abdjae@fst.unair.ac.id, ${ }^{2}$ ikuswandari94@gmail.com, ${ }^{3}$ cicik-a@fst.unair.ac.id
}

\begin{abstract}
Abstrak
Kegiatan pengabdian kepada masyarakat ini bertujuan untuk meningkatkan kompetensi guru dalam menyusun instrumen evaluasi pembelajaran yang bermutu berbasis thinking analysis yaitu pembuatan soal kategori High Order Thinking Skill (HOTS). Kegiatan ini diawali dengan pelatihan penyusunan soal HOTS dengan peserta guru mata pelajaran matematika tingkat SMP yang tergabung dalam MGMP Matematika Kabupaten Jember sebanyak 56 orang. Kegiatan berikutnya adalah penyusunan soal oleh peserta didampingi oleh tim pelaksana pengmas dilanjutkan dengan proses telaah soal. Berdasarkan hasil pengabdian ini secara keseluruhan terlihat bahwa kemampuan guru dalam menyusun soal kategori HOTS masih perlu ditingkatkan baik sisi penguasaan materi maupun teknis penyusunan soal yang baik. Kegiatan pelatihan ini diakhiri dengan evaluasi atas pelaksanaan kegiatan maupun hasil penyusunan soal oleh peserta. Evaluasi dilaksanakan terintegrasi dengan kegiatan rutin MGMP Matematika tingkat SMP di Kabupaten Jember. Luaran kegiatan ini adalah laporan kegiatan, video kegiatan, serta buku kumpulan seluruh soal yang disusun peserta.
\end{abstract}

Kata Kunci: Profesionalitas, kompetensi, instrumen evaluasi pembelajaran, High Order Thinking Skill (HOTS)

\begin{abstract}
This community service aims to improve teachers' competences in developing quality learning evaluation instruments based on thinking analysis, namely making questions with High Order Thinking Skill (HOTS) category. Participants were 56 junior high school mathematics teacher who were members of the Mathematics MGMP Jember. This activity started with some lectures on how to construct HOTS questions. Then the participants constructed HOTS questions accompanied by the community service team; it is also followed by a question review process.Based on the analysis results, it shows that the ability of the teachers in constucting the HOTS questions still needs to be improved both in terms of mastering theory and practice. This activity ended with an evaluation of the HOTS questions that had been made by the participants. The evaluation results were delivered during the routine Mathematics MGMP meeting at the junior high school level in Jember. The output of this activity is the community service report, video of the activity, as well as a collection of HOTS questions constucted by the participants.
\end{abstract}

Keywords: Professionalism, competences, learning evaluation instruments, High Order Thinking Skill (HOTS) 


\section{PENDAHULUAN}

Kabupaten Jember sebagai daerah otonom, memiliki batas-batas teritorial, luas wilayah, kemampuan ekonomi, potensi daerah, sosial politik dan sosial budaya serta sumber daya manusia. Kondisi obyektif yang demikian dapat mengungkapkan berbagai karakteristik sumberdaya alam, komoditas yang dihasilkan, mata pencaharian penduduk, keadaan ekonomi dan sosial budaya yang mencerminkan kekuatan suatu kompetensi daerah, sekaligus beragam permasalahan yang dihadapinya (http://jember.info/info/kondisi-umum).

Pada tiga tahun terakhir, beberapa kecamatan di Kabupaten Jember menjadi lokasi kuliah kerja nyata $(\mathrm{KKN})$ mahasiswa Universitas Airlangga. Kegiatan yang diberi nama KKN-BBM (Kuliah Kerja NyataBelajar Bersama Masyarakat) Tematik telah menjalin komunikasi dua arah yang sangat baik dan sangat dinamis antara Universitas Airlangga dengan pemerintah Kabupaten Jember. Adanya mahasiswa KKN tersebut telah memberi manfaat terkait pemberdayaan masyarakat di berbagai bidang. Kegiatan KKN mahasiswa juga difokuskan pada lembaga pendidikan misalnya di SD atau SMP yang ada di lokasi KKN dengan sasaran siswa sekolah tersebut. Selain itu, mahasiswa juga meluangkan waktu untuk memberi bantuan belajar bagi siswa SD dan SMP yang dilakukan di posko tempat tinggal mahasiswa KKN. Khusus pada mata pelajaran matematika, informasi dari mahasiswa KKN menunjukkan bahwa siswa SD/SMP masih kurang memahami pola pikir analitis dalam mengerjakan soal. Hal ini kemungkinan disebabkan oleh kurang terlatihnya siswa menyelesaikan soal yang termasuk kategori membutuhkan daya nalar tinggi. Hal ini masuk dalam domain kognitif,
Mullis dkk (2012) menyatakan bahwa domain ini terdiri dari pengetahuan, penerapan dan penalaran.

Studi pendahuluan melalui survei ke lokasi tempat pelaksanaan KKN dan wawancara dengan ketua Musyawarah Guru Mata Pelajaran (MGMP) Matematika. Berdasarkan hasil tersebut, terungkap bahwa kualitas pembelajaran khususnya bidang studi Matematika masih perlu ditingkatkan. Peningkatan ini meliputi seluruh aspek penyelenggaraan pendidikan, mulai dari metode, model, dan media pembelajaran yang diterapkan bahkan sampai evaluasi hasil pembelajaran. Peningkatan kualitas pembelajaran ini juga merupakan prioritas dan tujuan strategis Dinas Pendidikan Kabupaten Jember untuk senantiasa meningkatkan profesionalitas guru, khususnya guru SMP.

Terkait dengan peningkatan daya nalar siswa, penyediaan instrumen evaluasi yang bermutu merupakan hal yang sangat penting untuk meningkatkan kompetensi dan daya nalar siswa. Daya nalar siswa dapat diasah oleh guru dengan penyediaan instrumen evaluasi pembelajaran bermutu yang dapat mengajak siswa berpikir analitis dan sistematis. Di sisi lain, sejalan dengan adanya penerapan soal kategori Higher Order Thinking Skill (HOTS) pada Ujian Nasional SMA juga perlu disikapi oleh siswa SMP untuk berlatih soal kategori HOTS. Harapannya dengan terbiasa mengerjakan soal semacam itu maka daya analitis siswa juga akan meningkat. Dengan demikian tujuan pembelajaran untuk meningkatkan kualitas siswa akan tercapai.

Soal dengan kategori HOTS adalah soal yang membutuhkan keterampilan berpikir tingkat tinggi untuk menyelesaikannya (Riyana, 2015). Indikator untuk mengukur soal jenis HOTS 
antara lain keterampilan menganalisis, mengevaluasi, dan menciptakan (Anderson \& Krathwohl, 2001). Informasi yang terkandung dalam soal harus dianalisis terlebih dahulu, kemudian dipilih metode untuk menyelesaikan soal tersebut (Rukmini, 2008). Bagi siswa dan guru yang belum terbiasa menyelesaikan soal HOTS, tentu akan menemui kesulitan dalam menggali informasi yang terkadang tidak tampak jelas. Oleh karena itu, keterampilan mengidentifikasi berbagai informasi yang tersurat maupun tersirat dalam suatu soal beserta implikasinya merupakan kemampuan yang harus diasah secara terusmenerus.

Berdasarkan uraian di atas, tim pelaksana pengabdian kepada masyarakat (pengmas) Universitas Airlangga melakukan pelatihan penyusunan soal kategori HOTS bagi guru SMP di Kabupaten Jember. Sasaran kegiatan adalah guru mata pelajaran Matematika SMP di seluruh wilayah Kabupaten Jember yaitu wilayah Pusat, Timur, Selatan, dan Barat. Selain itu, informasi dari Kepala Bidang Sekolah Menengah Dinas Pendidikan Kabupaten Jember diperoleh keterangan bahwa pelatihan penyusunan soal HOTS memang pernah diberikan dan diikuti oleh satu orang guru per mata pelajaran di tiap sekolah. Artinya hanya sebagian kecil $( \pm 10 \%)$ guru yang mengikuti kegiatan tersebut dan pelaksanaannya belum sampai pada aspek evaluasi. Dengan demikian masih sangat banyak guru yang belum pernah mengikuti kegiatan pelatihan penyusunan soal HOTS. Dengan demikian diharapkan para guru mata pelajaran Matematika tidak hanya di wilayah KKN mahasiswa Universitas Airlangga tetapi juga di wilayah lain Kabupaten Jember dapat mengikuti kegiatan ini.

\section{METODEPELAKSANAAN}

Kegiatan pengabdian kepada masyarakat ini dilaksanakan dalam bentuk pelatihan penyusunan instrumen evaluasi pembelajaran khususnya penyusunan soal kategori Higher Order Thinking Skill (HOTS) selama satu hari. Bentuk pelatihan adalah ceramah dan diskusi tentang materi dilanjutkan dengan pendampingan penyusunan soal kategori HOTS melalui sesi kelas paralel. Selanjutnya peserta diberi tugas membuat soal dalam kategori HOTS. Hasil penyusunan soal selanjutnya ditelaah dan dikembalikan ke peserta jika sekiranya perlu diperbaiki. Bagian akhir dari kegiatan berupa evaluasi dan umpan balik. Evaluasi dilaksanakan bertepatan dengan agenda kegiatan MGMP Matematika wilayah Jember Barat.

Kegiatan ini dilaksanakan secara kemitraan atau kolaborasi antara tim pelaksana yang terdiri dari dosen Departemen Matematika Fakultas Sains dan Teknologi Universitas Airlangga dengan guru Matematika SMP yang tergabung dalam Musyawarah Guru Mata Pelajaran (MGMP) Matematika seluruh wilayah di Kabupaten Jember serta Dinas Pendidikan Kabupaten Jember. Kemudian kegiatan dilaksanakan di SMP Negeri 2 Tanggul.

\section{HASIL DAN PEMBAHASAN}

Secara garis besar kegiatan pengmas ini dibagi menjadi empat sub kegiatan yaitu: pelatihan, telaah soal, evaluasi dan umpan balik, serta luaran kegiatan. Masing-masing sub kegiatan akan diuraikan berikut ini.

\subsection{Pelatihan}

Kegiatan pelatihan dilakukan selama satu hari, dilaksanakan pada tanggal 27 Juli 2019. Pelatihan diikuti oleh guru Matematika SMP se wilayah Kabupaten Jember sebanyak 56 
orang. Adapaun rangkaian aktivitas pelatihan sebagai berikut:

1. Pemberian materi tentang 'Apa itu HOTS dan Mengapa Harus HOTS?' dilanjutkan materi tentang 'Teknis Penyusunan Soal HOTS' Materi disampaikan dengan metode ceramah dan diskusi disertai pemberian contohcontoh soal kategori HOTS dan bukan HOTS.

2. Praktik langsung penyusunan soal HOTS pada kelas-kelas kecil (paralel). Setiap peserta masuk dalam kelas paralel (kelas VII, VIII, atau IX) sesuai dengan tugas mereka mengajar di sekolah masing-masing. Dalam praktik penyusunan soal HOTS ini, peserta dipandu oleh seorang narasumber dan beberapa instruktur. Hasil praktik penyusunan soal HOTS minimal satu soal untuk tiap perserta dan dikumpulkan kepada panitia pengmas pada akhir sesi praktik.

3. Pemberian tugas menyusun soal HOTS yang terdiri dari tiga soal pilihan ganda dan dua soal uraian bagi setiap peserta. Ketentuan terkait pembuatan soal diberikan kepada peserta. Soal yang dibuat dikirimkan ke panitia pengmas untuk diteruskan ke proses telaah.

Berdasarkan pelatihan ini, pemahaman peserta terkait dengan HOTS sebesar 84,36 $\%$

\subsection{Telaah Soal}

Dari 56 peserta yang mengikuti pelatihan, sebanyak 34 orang telah mengirimkan soal ke panitia pengmas. Selanjutnya soal-soal tersebut ditelaah oleh tim penelaah yang terdiri dari dosen dan mahasiswa. Instrumen telaah dan kriteria soal yang diterima telah disusun oleh tim pengmas. Salah satu kriteria yang ditelaah adalah orisinalitas (keaslian) soal yang dibuat. Kriteria ini menjadi kriteria kunci yang diutamakan dalam proses telaah. Hal ini didasarkan pada pertimbangan bahwa para guru harus dapat berkreasi mengeluarkan ideide kreatif dalam menyusun soal dengan tujuan agar nantinya para guru senantiasa terpacu untuk membuat soal bermutu baik. Berprinsip pada orisinalitas, selayaknya para guru menghargai pembuat soal lainnya dengan cara tidak menjiplak soal buatan orang lain, karena hal tersebut dapat dikategorikan sebagai tindakan plagiat. Oleh karena itu, kriteria keaslian soal merupakan syarat utama sebuah soal dapat dilanjutkan ke proses telaah berikutnya.

Pada telaah tahap I, dari 56 peserta hanya 34 orang yang telah mengumpulkan masing-masing lima soal. Terdapat beberapa kondisi terkait soal yang dibuat peserta, yaitu 1) tidak memenuhi aspek orisinalitas; 2) soal yang disusun belum memenuhi kriteria HOTS; dan 3) kurang memenuhi kaidah penyusunan soal yang baik. Bagi soal dengan kriteria di atas, tim pelaksana segera mengirim umpan balik kepada peserta untuk mengganti/memperbaiki soal yang dibuat.

Pada telaah tahap II, dari 34 peserta yang telah diberi masukan hanya 8 peserta yang mengirim kembali hasil perbaikannnya ke tim pelaksana. Hasil telaah secara umum dapat dikatakan bahwa 1) sudah memenuhi aspek orisinalitas; 2) soal yang disusun sudah memenuhi kriteria HOTS; dan 3) sudah memenuhi kaidah penyusunan soal yang baik. Pada telaah tahap III, dilakukan evaluasi secara keseluruhan terkait penugasan dan hasil penugasan.

\subsection{Evaluasi dan Umpan Balik}

Evaluasi dan umpan balik pelaksanaan kegiatan secara garis besarnya dibagi menjadi dua bagian, yaitu evaluasi pelaksanaan pelatihan dan evaluasi hasil penyusunan soal yang dibuat peserta. 
Pertama adalah evaluasi pelaksanaan pelatihan yang dilakukan dalam bentuk penilaian kegiatan pelatihan oleh peserta melalui pengisian angket yang terdiri dari serangkaian pertanyaan pilihan ganda maupun pertanyaan terbuka. Pengisian angket dilakukan pada akhir kegiatan pelatihan. Kedua adalah evaluasi atas penyusunan soal yang telah dibuat peserta. Kegiatan evaluasi kedua ini dilaksanakan pada tanggal 3 Oktober 2019 bertempat di SMP Negeri 2 Tanggul bersamaan dengan kegiatan rutin MGMP Matematika.

Hasil evaluasi pertama yaitu pengisian angket yang terdiri dari serangkaian pertanyaan menunjukkan jawaban berikut.

1. Materi pelatihan merupakan hal yang baru $(56,25 \%)$ sedang $20,83 \%$ menyatakan sebagai hal yang biasa.

2. Materi yang diberikan dalam pelatihan membantu peserta dalam melaksanakan tugas sebagai seorang Guru $(82,29 \%)$, sisanya menyatakan cukup membantu.

3. Pelatihan dinilai sangat bermanfaat dalam pengembangan profesi Guru (86,46\%), sisanya menyatakan cukup bermanfaat.

4. Pelaksanaan pelatihan dinilai sangat efektif oleh $78,72 \%$ peserta.

5. Kemampuan nara sumber dalam menyajikan materi dinilai sangat baik oleh $79,17 \%$ peserta sementara $18,75 \%$ menilai cukup.

6. Kemampuan nara sumber dalam penguasaan kelas dinilai sangat baik oleh $31,25 \%$ peserta dan $68,75 \%$ peserta menilai baik.

7. Penggunaan media yang digunakan dalam pelatihan dinilai interaktif oleh $67,02 \%$ peserta sedang $14,89 \%$ menilai sangat interaktif.

Sementara dari pertanyaan terbuka dapat ditarik kesimpulan bahwa:
1. Sikap dan pelayanan panitia pengmas sejak proses registrasi hingga pelaksanaan dinilai bagus, baik, ramah, disiplin, dan sabar.

2. Jika diadakan pelatihan berikutnya, topik yang dibutuhkan peserta adalah pendalaman HOTS termasuk pengajarannya $(31,25 \%)$, pembelajaran berbasis IT $(22,92 \%)$, penilaian aspek keterampilan dalam pembelajaran $(18,75 \%)$, dan perangkat dan media pembelajaran $(12,5 \%)$.

Dari hasil angket tersebut dapat disimpulan bahwa pelatihan yang dilakukan memang dibutuhkan oleh peserta untuk meningkatkan kompetensinya.

Evaluasi kedua dilakukan dengan mengkaji bersama soal-soal yang telah dibuat oleh peserta. Review diberikan oleh tim pengmas disertai dengan diskusi dan tanya jawab dengan peserta terutama dikaitkan dengan rambu-rambu soal HOTS baik tentang kriteria soal HOTS maupun terkait dengan teknis penyusunan soal. Beberapa soal yang ditampilkan diberi komentar oleh peserta yang kemudian diarahkan oleh tim pengmas.

\subsection{Luaran Kegiatan}

Luaran kegiatan pengabdian kepada masyarakat ini adalah artikel ilmiah pada jurnal ber-ISSN atau prosiding ber ISBN dari seminar nasional, artikel pada media massa cetak/elektronik, video kegiatan dan peningkatan keberdayaan mitra. Di samping itu terdapat luaran tambahan berupa kumpulan soal yang dibukukan.

Secara umum seluruh rangkaian kegiatan pengabdian kepada masyarakat ini telah terlaksana sesuai jadwal yang disusun dan tujuan yang diharapkan. Pelaksanaan pelatihan, pemberian tugas membuat soal HOTS, proses telaah soal, hingga pelaksanaan evaluasi telah dilakukan dengan 
melibatkan seluruh tim pelaksana. Kegiatan ini mendapat respon yang sangat baik dari para peserta, tercermin dalam kehadiran 93,33\% peserta dari seluruh peserta yang diundang dan mengkuti acara dari awal hingga akhir, sangat antusias saat sesi diskusi dan pendalaman di kelas paralel, mengumpulkan tugas sesuai waktu yang diberikan, serta hasil isian angket yang sangat konstruktif. Respon yang sangat baik juga ditunjukkan oleh Kepala Dinas Pendidikan Kabupaten Jember yang berkontribusi dalam memberikan ijin pelaksanaan kegiatan, mengundang para guru untuk ikut pelatihan, hadir pada saat pelatihan berlangsung.

\section{KESIMPULAN}

Berdasarkan hasil dan pembahasan serta seluruh rangkaian kegiatan pengabdian kepada masyarakat yang telah terlaksana, maka dapat disimpulkan sebagai berikut:

1. Kemampuan para guru dalam pemahaman materi matematika masih perlu ditingkatkan, terutama kompetensi mereka terkait substansi/materi pembelajaran.

2. Kemampuan para guru dalam menyusun soal kategori HOTS masih perlu ditingkatkan, baik dari sisi teknis penyusunan maupun kelogisan soal yang dibuat.

\section{REFERENSI}

Anderson, L. W. \& Krathwohl, D. R. 2001. A taxonomy for learning, teaching, and assessing: A revision of Bloom's taxonomy of educational objectives. New York, NY: Addison Wesley Longman.

Kondisi Umum Kabupaten Jember, http://jember.info/info/kondisi-umum, diakses tanggal 27 Februari 2019.

Mullis, I. V. S., Martin, M. O., Foy, P., \& Arora, A. 2012. TIMSS 2011 international result in mathematics. Chestnut Hill, MA: TIMSS \& PIRLS International Study Center Lynch School of Education, Boston College.

Riyana, A, 2015. Taksonomi Bloom

(Ranah Kognitif, Afektif, dan Psikomotor), https://kangmaszakki.wordpress.com/ 2017/09/23/taksonomi-bloom-ranahkognitif-afektif-dan-psikomotor/, diakses tanggal 27 Februari 2019.

Rukmini, E, 2008. Deskripsi Singkat Revisi Taksonomi Bloom, Majalah Ilmiah Pembelajaran. No 2, 02167999 